\title{
Identifikasi dan Penetapan Kadar Kinin Ekstrak Kulit Batang Kina (Cinchona succirubra) secara KLT-Densitometri
}

\section{Identification and Determination of Quinine Stem Bark (Cinchona succirubra) by TLC-Densitometry}

\author{
Ni Kadek Ayu Pramesti ${ }^{1 \bullet}$, Ni Putu Vyra Ginanti Putri ${ }^{1}$, Ida Ayu Mas Laksmi Dewi ${ }^{1}$, \\ Mirilia Vital Moreira ${ }^{1}$, Lupu Rina Antarini ${ }^{1}$ \\ ${ }^{1}$ Program Studi Farmasi, Fakultas Matematika dan IImu Pengetahuan Alam, Universitas Udayana, Bali
}

\begin{abstract}
Abstrak: Kulit batang kina (Cinchona succirubra Cortex) merupakan salah satu bagian tanaman yang menghasilkan metabolit sekunder yaitu alkaloid kinin dan memiliki aktifitas farmakologi. Selain kandungan kinin, dalam kulit batang kina juga terdapat berbagai senyawa kimia lainnya, yakni kinidin, sinkonin, dan sinkonidin. Adanya kandungan senyawa lain dapat mengurangi efek farmakologi yang dihasilkan oleh kinin bahkan dapat saling meniadakan satu sama lain. Pemilihan metode pemisahan dan isolasi yang tepat merupakan faktor penting yang akan mempengaruhi kemurnian senyawa tunggal yang diperoleh. Ekstraksi dengan metode Soxhlet dan identifikasi golongan dengan metode screening fitokimia. Fraksinasi dengan metode esktraksi cair-cair dan kromatografi vakum cair. Isolasi dengan metode kromatografi preparatif dan metode KLT-Densitometri. Dari proses Ekstraksi metode Soxhlet didapat filtrat dengan warna coklat kemerahan. Hasil skrining fitokimia adalah positif golongan triterpenoid dan alkaloid. Ekstraksi cair-cair didapat hasil fraksi air, fraksi etil asetat I dan fraksi etil asetat II. Hasil KLT dan identifikasi pereaksi kimia adalah positif mengandung kinin pada fraksi etil asetat II. Berdasarkan hasil penelitian dengan metode KLT-Densitometri menunjukkan bahwa ekstrak kulit batang kina positif mengandung senyawa kinin dengan penetapan kadar total kinin dalam standar kinin menghasilkan nilai rata - rata \% recovery yaitu 100,442 \% dan kadar total kinin dalam subfraksi KLT-P I dan II secara berturut-turut menghasilkan kadar sebesar 0,402612 $\mathrm{mg} / \mathrm{mL}$ dan $0,155830 \mathrm{mg} / \mathrm{mL}$.
\end{abstract}

Kata Kunci: Cinchona succirubra Cortex, fraksi, kinin, KLT-Densitometri, KLT-Preparatif.

\begin{abstract}
The stem bark of quinine (Cinchona succirubra Cortex) is one part of the plant that produces secondary metabolites, which is alkaloids in the form of quinine and have pharmacological activity. In addition to the content of quinines, in the stem bark of quinine there are also various other chemical compounds, there are quinidine, synconine, and synconidine. The content of other compounds can reduce the pharmacological effects produced by quinine and can even cancel each other out. The selection of the appropriate separation and isolation method is an important factor that will affect the purity of the single compound obtained. Extraction using the Soxhlation method, identification of groups using the phytochemical screening method. Fractionation using liquid-liquid extraction and vacuum liquid chromatography. Isolation by preparative chromatography method and TLCDensitometry method. Soxhlet extraction obtained the filtrate with a reddish-brown color. Phytochemical screening was positive for triterpenoids and alkaloids. Liquid-liquid extraction resulted in the water fraction, ethyl acetate fraction I and ethyl acetate fraction II. TLC and identification of positive chemical reagents containing quinine in ethyl acetate fraction II. Based on the results of the research using the TLC-Densitometry method, it was shown that the quinine bark extract was positive for Quinine with the Determination of the total quinine level in the quinine standard resulted in an average value of $\%$ recovery was $100.442 \%$ and the total quinine content in the TLC-P I and II subfraction resulted was $0.402612 \mathrm{mg} / \mathrm{mL}$ and 0.155830 $\mathrm{mg} / \mathrm{mL}$.
\end{abstract}

Keywords: Cinchona succirubra Cortex, fraction, quinine, TLC-Densitometry, TLC-Preparative.

\footnotetext{
•email korespondensi: ayupramesti844@gmail.com
} 


\section{PENDAHULUAN}

Pemanfaatan tanaman sebagai bahan baku obat mulai sering digunakan terkait dengan berbagai macam metabolit sekunder yang dapat dihasilkan oleh tanaman. Setiap tanaman menghasilkan metabolit sekunder yang berbeda-beda dengan jumlah atau kadar yang berbeda. Jenis senyawa metabolit sekunder yang biasa ditemukan dalam tanaman, antara lain: alkaloid, flavonoid, steroid, dan terpenoid (Amalia, Parwati, dan Simanjuntak, 2004). Salah satu tanaman yang sering digunakan karena aktifitas farmakologinya adalah tanaman kina (Cinchona succirubra). Kina memiliki aktivitas sebagai anti malaria, anti piretik serta stomakika (obat sakit perut). Kandungan kimia kina berupa alkaloid dengan kadar tidak kurang dari $7 \%$ yang dihitung sebagai kinin. Bagian tanaman yang banyak digunakan adalah kulit batangnya. Kinin dapat digunakan sebagai obat malaria dikarenakan memiliki efektivitas yang baik terhadap semua jenis plasmodium dan juga efektif sebagai sizontosida dan gametosida (Harijanto, 2006).

Selain kandungan kinin, dalam kulit batang kina juga terdapat berbagai senyawa kimia lainnya, yakni kinidin, sinkonin, dan sinkonidin. Keempat jenis senyawa alkaloid tersebut memiliki khasiat sebagai antimalaria. Namun, kinin merupakan alkaloid yang paling sering digunakan karena kandungannya dalam kulit batang kina paling besar dibandingkan alkaloid lainnya. Alkaloid merupakan senyawa metabolit sekunder terbanyak yang memiliki atom nitrogen, yang ditemukan dalam jaringan tumbuhan dan hewan. (Wink, 2008). Kandungan alkaloid lain serta senyawa lain dalam kulit batang kina (C. succirubra) dapat menyebabkan efek farmkologi yang ditimbulkan tidak optimal saat penggunaan langsung. Adanya kandungan senyawa lain dapat mengurangi efek farmakologi yang dihasilkan oleh kinin bahkan dapat saling meniadakan satu sama lain. Selain itu, senyawa lain yang terkandung dapat menyebabkan efek farmakologi lain yang tidak diinginkan. Kandungan kimia yang banyak dalam kulit batang kina, menyebabkan perlunya dilakukan suatu proses pemisahan, isolasi yang kompleks yaitu deffating, ekstraksi Soxhlet, skrining fitokimia, ekstraksi cair- cair, KLT, kromatografi vakum cair, KLT fraksinasi, KLT preparatif, KLT subfraksinasi dan terakhir KLT Densitometri. Pemilihan metode pemisahan dan isolasi yang tepat merupakan faktor penting yang akan mempengaruhi kemurnian senyawa tunggal yang diperoleh berupa kinin.

\section{METODE PENELITIAN}

\section{Tempat dan Waktu Penelitian}

Penelitian dilaksanakan di Laboratorium Fitokimia dan Farmakognosi Program Studi Farmasi, Fakultas Matematika dan IImu Pengetahuan Alam, Universitas Udayana. Waktu pelaksanaan dilakukan pada bulan Agustus hingga Desember 2019.

\section{Alat dan Bahan}

Alat yang digunakan yaitu timbangan analitik, beaker glass, botol vial, pipet tetes, pipet ukur, gelas ukur, labu ukur, bulbfiller, sendok tanduk, seperangkat alat sokhletasi, oven, waterbath, corong pisah, statif dan buret, chamber, kolom vakum, mikropipet $2 \mu \mathrm{L}$, plat KLT Al-Silika Gel GF254, CAMAG TLC Scanner 5.

Bahan yang digunakan yaitu serbuk kulit batang kina (Cinchona succirubra Cortex), metanol, $\mathrm{HCl} 37 \% \mathrm{~b} / \mathrm{b}$, akuades, eter, kloroform, asam asetat, $\mathrm{H}_{2} \mathrm{SO}_{4} 37 \% \mathrm{~b} / \mathrm{b}$, standar kinin dan etil asetat.

\section{Defatting dan Ekstraksi dengan Metode Soxhlet}

Serbuk kulit batang kina sebanyak 20gram di-Soxhlet menggunakan metanol sebanyak $130 \mathrm{~mL}$. Ekstraksi metode Soxhlet dilakukan pada suhu $70^{\circ} \mathrm{C}$ dan dilakukan beberapa kali sirkulasi hingga warna pelarut pada kelongsong berwarna bening. Disaring filtrat yang diperoleh dan diukur volumenya. Kemudian ditampung filtrat pada cawan porselin dan diuapkan hingga diperoleh ekstrak kental (Leliqia dkk., 2019).

\section{Skrining Fitokimia}

Ekstrak kulit batang kina sebanyak 10mg dilarutkan dengan $10 \mathrm{~mL}$ metanol sebagai larutan uji. Uji alkaloid yaitu ekstrak kulit batang kina diuapkan sebanyak $2 \mathrm{~mL}$, kemudian dilarutkan ke dalam $5 \mathrm{~mL}$ $\mathrm{HCl} 2 \mathrm{~N}$. Pengujian adanya senyawa alkaloid 
dilakukan dengan perekasi Wagner, Mayer dan Dragendrof, adanya senyawa alkaloid ditunjukkan dengan terbentuknya endapan coklat pada penambahan perekasi Wagner, warna kuning pada penambahan pereaksi Mayer dan warna jingga pada penambahan pereaksi Dragendrof. Uji flavonoid digunakan larutan aseton, asam oksalat, dan eter kemudian diamati di bawah UV $366 \mathrm{~nm}$, larutan berflouresensi kuning intensif menandakan adanya senyawa flavonoid. Uji steroid dan triterpenoid dilakukan dengan menggunakan pereaksi Liebermann-Burchard, asam asetat anhidrat, dan asam sulfat pekat. Terbentuknya cincin keclokatan atau violet pada perbatasan larutan menandakan positif triterpenoid, sedangkan apabila muncul cincin biru kehijauan menandakan positif steroid. Uji saponin yaitu larutan uji dikocok secara vertikal selama 10 detik, kemudian didiamkan selama 10 detik. Diamati pembentukan busa, apabila terjadi pembentukan busa setinggi $1-10 \mathrm{~cm}$ yang stabil selama \pm 10 menit menunjukkan adanya saponin dan ditambahkan 1 tetes $\mathrm{HCl} 2 \mathrm{~N}$ agar busa tidak menghilang (Leliqia dkk., 2019).

\section{Ekstraksi Cair-Cair}

Sebanyak 300mg serbuk kulit batang kina dilarutkan dengan $10 \mathrm{~mL}$ larutan $\mathrm{H}_{2} \mathrm{SO}_{4} \quad 10 \%$. Kemudian dimasukkan ke dalam corong pisah digojog lalu ditambahkan $20 \mathrm{~mL}$ etil asetat. Ditambahkan $10 \mathrm{~mL}$ amonia cair, dan ditampung kedua fase hingga diperoleh fraksi air dan fraksi etil asetat. Kemudian fraksi diuapkan dengan oven suhu $40^{\circ} \mathrm{C}$ (Leliqia dkk., 2019).

\section{KLT dan Identifikasi Alkaloid Kinin dengan Pereaksi Kimia}

Masing - masing fraksi air, etil asetat $\mathrm{l}$, etil asetat II, standar kinin sulfat, dan ekstrak metanol ditotolkan sebanyak $6 \mu \mathrm{L}$ pada plat KLT Al Silika Gel GF 254, kemudian plat dimasukkan ke dalam chamber yang telah dijenuhkan dengan fase gerak kloroform : metanol (9:1) v/v. Plat dielusi hingga batas jarak pengembangan, kemudian dideteksi di bawah sinar UV $254 \mathrm{~nm}$ dan $366 \mathrm{~nm}$. Plat disemprot dengan perekasi semprot $\mathrm{H}_{2} \mathrm{SO}_{4} 10 \%$, diamati kembali plat di bawah sinar UV $254 \mathrm{~nm}$ dan $366 \mathrm{~nm}$, ditandai spot yang diduga kinin dan dihitung Rf masing-masing spot (Leliqia dkk., 2019).

\section{Kromatografi Vakum Cair}

Diawali dengan penyiapan fraksi etil asetat, penyiapan kolom, dan elusi dimana Fraksi ditaburkan dibagian atas kolom yang sudah di kemas, dielusi secara gradien masing-masing dengan $30 \mathrm{ml}$ campuran eluen kloroform: metanol (9:1) v/v sampai (5:5) v/v. Setiap fraksi ditampung dalam botol coklat dan ditiap fraksi diuapkan pelarutnya kemudian ditimbang (Leliqia dkk., 2019).

\section{KLT Hasil Fraksinasi Vakum Cair}

Ditotolkan fraksi etil asetat : metanol (7:3) v/v, fraksi etil asetat : metanol (5:5) v/v, fraksi etil asetat: metanol (3:7) v/v, dan standar kinin pada plat KLT yang sudah diaktivasi. Dimasukkan plat ke dalam chamber yang sudah dijenuhkan dengan fase gerak kloroform : metanol (9:1) v/v. Plat dianginanginkan, kemudian diamati di bawah sinar UV 254 $\mathrm{nm}$ dan $366 \mathrm{~nm}$. Disemprotkan plat KLT dengan pereaksi semprot $\mathrm{H}_{2} \mathrm{SO}_{4} 10 \%$, lalu diamati kembali di bawah sinar UV $254 \mathrm{~nm}$ dan $366 \mathrm{~nm}$ (Leliqia dkk., 2019).

\section{Kromatografi Lapis Tipis Preparatif}

Ditotolkan larutan uji pada lempeng KLT dalam bentuk pita, lempeng dielusi di dalam chamber yang telah dijenuhkan. Plat yang telah dielusi diamati di bawah sinar UV 254 dan 366 nm. Ditandai bercak yang positif mengandung kinin, bercak tersebut diambil dengan mengerok silika pada plat KLT dengan spatula. Alkaloid kinin yang terikat pada silika diekstraksi dengan pelarut campuran $\mathrm{CHCl} 3$ : $\mathrm{MeOH}(9: 1 \mathrm{v} / \mathrm{v})$ (Leliqia dkk., 2019).

\section{Kromatografi Lapis Tipis Hasil Subfraksinasi}

Subfraksi hasil KLT preparatif dilarutkan dengan $1 \mathrm{~mL}$ metanol p.a. Ditotolkan pada plat hasil KLT preparatif dan standar kinin. Plat dimasukkan ke dalam chamber yang telah jenuh dan dielusi, kemudian spot pada plat dideteksi di bawah sinar UV $254 \mathrm{~nm}$ dan $366 \mathrm{~nm}$. Plat disemprot dengan pereaksi $\mathrm{H}_{2} \mathrm{SO}_{4} 10 \%$, kemudian plat diamati lagi di bawah sinar UV $254 \mathrm{~nm}$ dan $366 \mathrm{~nm}$ ditandai spot yang 
diduga senyawa kinin dan dihitung nilai rf masingmasing spot (Leliqia dkk., 2019).

\section{Identifikasi KLT Densitometri}

Ditotolkan larutan standar kinin pada plat KLT menggunakan pipet kapiler sebanyak $2 \mu \mathrm{L}, 4 \mu \mathrm{L}, 6 \mu \mathrm{L}$, $8 \mu \mathrm{L}$ dan $10 \mu \mathrm{L}$, kemudian ditotolkan larutan subfraksinasi KLT-P masing-masing sebanyak $6 \mu \mathrm{L}$ dengan 3 kali pengulangan. Plat dielusi dan dikeluarkan dari chamber dan dikeringkan dengan cara diangin-anginkan. Plat dimasukkan ke alat TLC Scanner, lalu diamati dengan densitometer, dibuat kurva kalibrasi dan persamaan regresi liniernya, kemudian dilakukan penetapan kadar kinin dalam sampel (Leliqia dkk., 2019).

\section{HASIL DAN PEMBAHASAN}

Deffating dan Estraksi Serbuk Kulit Batang Kina dengan Metode Soxhlet

Tabel 1. Jumlah Ekstrak Kulit Batang Kina Hasil Ekstraksi Metode Soxhlet

\begin{tabular}{ccc}
\hline Nama Bahan & Warna & Jumlah \\
\hline $\begin{array}{c}\text { Ekstrak metanol hasil } \\
\text { Soxhlet }\end{array}$ & $\begin{array}{c}\text { Coklat } \\
\text { kemerahan }\end{array}$ & $18,6 \mathrm{~g}$ \\
\hline
\end{tabular}

Proses pemisahan, isolasi, dan identifikasi alkaloid dari serbuk simplisia kulit batang kina (Cinchona succirubra) diawali dengan proses ekstraksi. Proses ekstraksi dilakukan untuk mengekstrak metabolit sekunder yang terdapat dalam serbuk kulit batang kina. Soxhlet merupakan rangkaian proses ekstraksi dimana selalu menggunakan pelarut baru yang pada umumnya dilarutkan dengan alat khusus yang disebut soklet sehingga terjadi ekstraksi berkelanjutan dengan jumlah pelarut yang relatif konstan (Depkes RI, 2014).

Dipilihnya ekstraksi Soxhlet karena metode Soxhlet memiliki beberapa keuntungan, diantaranya sedikitnya penggunaan pelarut sehingga dapat menyaring senyawa yang terdapat dalam simplisia lebih banyak dalam waktu lebih singkat dibandingkan dengan maserasi. Namun, metode Soxhlet juga memiliki kelemahan yaitu tidak dapat digunakan untuk senyawa-senyawa yang tidak tahan terhadap pemanasan. Metode Soxhlet juga dipilih untuk proses ekstraksi kinin karena kinin memiliki titik lebur $173-175^{\circ} \mathrm{C}$, yang berarti kinin akan tahan (stabil) terhadap pemanasan (Merck, 2001).

Penggunaan metanol sebagai pelarut penyari karena metanol merupakan pelarut universal yang sifatnya semipolar, sehingga mampu masuk ke sel tanaman dan akan terjadi pengembangan sel, dan kemudian akan terjadi perpindahan komponen dan difusi bahan yang diekstraksi ke luar sel serta metanol memiliki kemampuan untuk mengendapkan protein dan menghibisi kerja enzim (Harborne, 1987). Selain itu karena alkaloid bersifat basa yang mudah larut dalam larutan beralkohol (Depkes RI, 1995). Pada penelitian ini proses ekstraksi Soxhlet dilakukan sebanyak 8 kali sirkulasi dengan waktu untuk tiap sirkulasi tertera pada tabel hasil. Untuk mendapatkan 8 kali sirkulasi waktu keseluruhan yang dibutuhkan adalah 3 jam 18 menit. Ekstrak hasil Soxhlet berwarna coklat kemerahan dengan volume ekstrak (filtrat) yaitu sebanyak 18,6 gram

\section{Skrining Fitokimia}

Tabel 2. Hasil Skrining Fitokimia

\begin{tabular}{cc}
\hline Golongan Senyawa & Hasil \\
\hline Flavonoid & - \\
Triterpenoid & + \\
Saponin & - \\
Alkaloid & + \\
\hline
\end{tabular}

Skrining fitokimia bertujuan untuk mengetahui kandungan senyawa yang terdapat dalam simplisia tumbuhan. Sebelum melakukan skrining fitokimia, dilakukan pembuatan larutan ekstrak uji terlebih dahulu. Hasil skrining fitokimia dipengaruhi oleh pemilihan pelarut karena pelarut berperan dalam melarutkan senyawa yang diinginkan. Metanol digunakan sebagai pelarut karena metanol merupakan perlarut yang bersifat universal sehingga dapat melarutkan semua komponen, baik yang bersifat polar, semi polar, maupun non polar. Metanol dapat menarik alkaloid, saponin dan flavonoid dari tanaman. Dalam skrining fitokimia pemilihan pelarut merupakan hal yang penting karena pelarut memiliki peran dalam melarutkan senyawa yang dikehendaki dan apabila pemilihan pelarut sudah tepat maka skrining 
fitokimia akan menunjukkan hasil yang tepat (Kristanti dkk., 2008).

Uji skrining fitokimia dalam penelitian ini adalah uji kandungan flavonoid, uji steroid dan triterpenoid, uji kandungan saponin, dan uji kandungan alkaloid. Dari hasil pengamatan, larutan ekstrak uji mengandung endapan berwarna coklat yang menunjukkan hasil positif alkaloid dengan pereaksi Wagner. Dan pada sampel positif mengandung steroid dan triterpenoid karena terbentuk cincin berwarna violet pada batas larutan. Hasil tersebut menunjukkan bahwa larutan ekstrak uji yang digunakan tidak mengandung steroid tetapi mengandung triterpenoid.

\section{Ekstraksi Cair-Cair}

Tabel 3. Hasil Ekstraksi Cair-Cair dan warna yang dihasilkan

\begin{tabular}{|c|c|c|}
\hline No & Hasil Fraksi & Warna \\
\hline 1 & $\begin{array}{l}\text { Fase etil asetat } \\
\text { Fase air }\end{array}$ & $\begin{array}{l}\text { Coklat kemerahan } \\
\text { Bening kekuningan }\end{array}$ \\
\hline 2 & $\begin{array}{l}\text { Fase etil asetat } \\
\text { Fase air }\end{array}$ & $\begin{array}{c}\text { Coklat kekuningan } \\
\text { Bening }\end{array}$ \\
\hline 3 & $\begin{array}{l}\text { Fase etil asetat } \\
\quad \text { Fase air }\end{array}$ & $\begin{array}{l}\text { Kekuningan } \\
\text { Bening }\end{array}$ \\
\hline 4 & $\begin{array}{l}\text { Fase etil asetat } \\
\text { Fase air }\end{array}$ & $\begin{array}{c}\text { Bening } \\
\text { Kecoklatan }\end{array}$ \\
\hline
\end{tabular}

Proses ekstraksi cair-cair dilakukan dalam 2

tahap. Tahap pertama merupakan defatting (menghilangkan lipid dan resin) dan tahap kedua adalah purification (pemurnian). Pertama dilakukan tahap defatting, ekstrak dalam asam sulfat dipartisi dengan cara dimasukkan ke dalam corong pisah lalu ditambahkan etil asetat sebanyak $20 \mathrm{~mL}$ kemudian dilakukan penggojogan dan dipartisi sebanyak dua kali. Digunakan etil asetat karena etil asetat bersifat nonpolar dan tidak menyatu dengan fase air sehingga dapat digunakan dalam ekstraksi cair-cair. Campuran dalam corong pisah kemudian digojog untuk memperluas kontak antar pelarut tidak saling campur sehingga terjadi perpindahan senyawa terlarut hingga mencapai keadaan kesetimbangannya diantara kedua pelarut.

Penggojogan dapat membantu proses distribusi analit di antara campuran pelarut. Setelah dilakukan penggojogan terbentuk dua lapisan yang tidak saling campur pada corong pisah, yaitu fase air pada lapisan bawah yang berwarna kuning bening dan fase organik pada lapisan atas yang berwarna coklat kemerahan. Hal ini dikarenakan bobot jenis etil asetat lebih kecil yaitu 0,894 - 0,898 g/mL (Moffat et al., 2005) dibandingkan bobot jenis air $0,9971 \mathrm{~g} / \mathrm{mL}$ (Moffat et al., 2005), sehingga membuat etil asetat berada pada bagian atas pada corong pisah. Selanjutnya fase air ditampung untuk dilakukan proses pemurnian. Proses kedua, dilakukan tahap pemurnian (purification) yang dilakukan untuk mendapatkan alkaloid pada fase air yang telah terbebas dari lipid dan resin.

\section{Kromatografi Lapis Tipis dan Identifikasi dengan Pereaksi Kimia}

Tabel 4. Pengamatan KLT sebelum disemprot dengan $\mathrm{H}_{2} \mathrm{SO}_{4} 10 \%$

\begin{tabular}{|c|c|c|c|}
\hline Pengamatan & Fraksi & Rf & HRf \\
\hline Hasil & Fraksi air: & & \\
\hline Pengamatan & Tidak ada spot & - & - \\
\hline KLT Sebelum & Fraksi Etil Asetat 1: & & \\
\hline disemprot & Tidak ada spot & - & - \\
\hline dengan $\mathrm{H}_{2} \mathrm{SO}_{4}$ & Fraksi Etil Asetat 2: & & \\
\hline $10 \%$ pada UV & - Spot DI & 0,175 & 17,5 \\
\hline \multirow[t]{6}{*}{$366 \mathrm{~nm}$} & - Spot DII & 0,275 & 27,5 \\
\hline & - Spot DIII & 0,375 & 37,5 \\
\hline & Fraksi Ekstrak Metanol: & & \\
\hline & Tidak ada spot & - & - \\
\hline & Fraksi Standar Kinin: & & \\
\hline & - Spot EI & 0,3125 & 31,25 \\
\hline Hasil & Fraksi air: & & \\
\hline Pengamatan & Tidak ada spot & - & - \\
\hline KLT Setelah & Fraksi Etil Asetat 1: & & \\
\hline disemprot & Tidak ada spot & - & - \\
\hline dengan $\mathrm{H}_{2} \mathrm{SO}_{4}$ & Fraksi Etil Asetat 2: & & \\
\hline $10 \%$ pada UV & - Spot DI & 0,25 & 25 \\
\hline \multirow[t]{5}{*}{$366 \mathrm{~nm}$} & Fraksi Ekstrak Metanol: & & \\
\hline & - Spot Al & 0,2375 & 23,75 \\
\hline & Fraksi Standar Kinin: & & \\
\hline & - Spot EI & 0,25 & 25 \\
\hline & - Spot Ell & 0,3125 & 31,25 \\
\hline
\end{tabular}

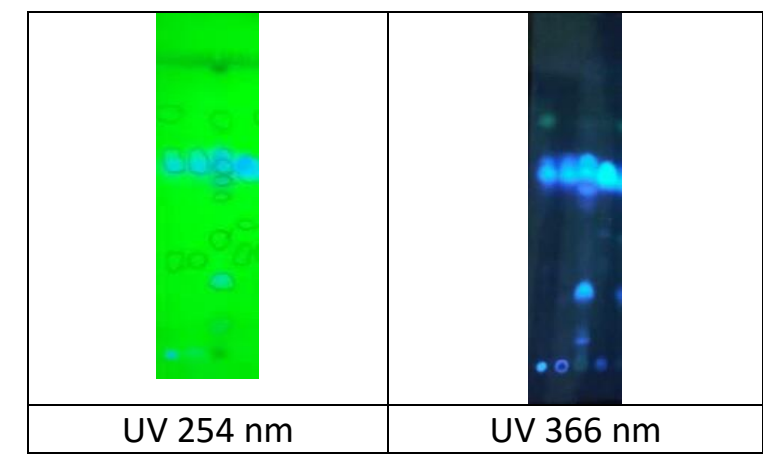

Gambar 1. Identifikasi KLT di bawah sinar UV $254 \mathrm{~nm}$ dan $366 \mathrm{~nm}$ sesudah disemprot $\mathrm{H}_{2} \mathrm{SO}_{4} 10 \%$

Kromatografi lapis tipis merupakan teknik pemisahan campuran yang didasarkan pada 
perbedaan kecepatan perambatan suatu komponen dalam medium tertentu yang banyak digunakan untuk tujuan analisis (Gandjar dan Rohman, 2007). Hasil pada UV 366 sebelum disemprot $\mathrm{H}_{2} \mathrm{SO}_{4} 10 \%$ menunjukkan penampakan kromatogram yang padam dengan spot-spot yang berpendar. Spot-spot tersebut merupakan analit hasil pemisahan. Nilai $\mathrm{Rf}$ dan HRf yang diperoleh dihitung, sehingga diperoleh nilai HRf fraksi etil asetat II adalah spot DI yaitu 17,5; spot DII yaitu 27,5; spot DIII yaitu 37,5 dan standar kinin spot El yaitu 31,25. Untuk fraksi air, fraksi etil asetat I, dan fraksi ekstrak metanol tidak ditemukan adanya spot.

Reagen kimia asam sulfat $10 \%$ yang digunakan dapat bereaksi dengan alkaloid kinin membentuk kinin sulfat. Senyawa yang terbentuk akan memberikan fluoresensi biru pada pengamatan di panjang gelombang $366 \mathrm{~nm}$ (Stahl, 1985). Hasil UV 366 setelah disemprot dengan $\mathrm{H}_{2} \mathrm{SO}_{4} \quad 10 \%$ menunjukkan fluoresensi biru yang mengindikasikan hasil positif adanya senyawa alkaloid, dengan nilai HRf diantaranya pada fraksi etil asetat II dengan spot DI 25; fraksi ekstrak metanol dengan spot Al yaitu 23,75; dan standar kinin dengan spot El yaitu 25 serta spot Ell yaitu 31,25. Untuk fraksi air dan fraksi etil asetat I tidak ditemukan adanya spot. Pengamatan pada UV 366 sebelum penyemprotan menunjukkan hasil pada fraksi etil asetat II terdeteksi kinin karena ditandai fluoresensi warna biru. Pengamatan hasil setelah dilakukan penyemprotan dengan menggunakan pereaksi semprot menunjukkan data yang lebih spesifik. Pengamatan pada UV 366 menunjukkan hasil terdeteksinya senyawa kinin pada fraksi etil asetat II spot DI, dan fraksi ekstrak metanol spot Al karena ditandai dengan adanya fluoresensi biru pada plat.

Hasil pengamatan spot di bawah UV $254 \mathrm{~nm}$ mengalami pemadaman bercak berdasarkan Rf standar kinin yang diperoleh yaitu 0,65 maka spot 1 (Rf 0,65) spot $2(\operatorname{Rf} 0,65)$, dan 3b (Rf 0,6625) merupakan senyawa kinin karena $R f$ yang didapat mendekati $\mathrm{Rf}$ standar kinin. Sedangkan pengamatan spot di bawah UV $366 \mathrm{~nm}$ berdasarkan rf standar kinin yaitu $(0,33 ; 0,43 ; 0,63)$ maka spot $1 b(\operatorname{Rf} 0,63)$, dan spot $3 e(\operatorname{Rf} 0,625)$ merupakan senyawa kinin karena $\mathrm{Rf}$ yang didapat mendekati Rf standar kinin dan dapat berpendar berwarna biru intensif. Hal ini sesuai dengan pustaka yang ada dimana disebutkan bahwa alkaloid kinin apabila bereaksi dengan $\mathrm{H}_{2} \mathrm{SO}_{4}$ akan memberikan fluoresensi biru intensif (Eagleson, 1993). Kinin mampu berfluoresensi karena memiliki struktur yang kaku dan kromofornya yang diperpanjang. Sistem rangkap terkonjugasi memiliki struktur yang planar dan kaku sehingga akan mampu menyerap secara kuat di daerah UV 200-800 nm pada radiasi elektromagnetik (Gandjar dan Rohman, 2007). Terjadi pengekoran pada hasil pengamatan akibat onsentrasi yang ditotolkan terlalu pekat sehingga banyak spot yang diperoleh dalam 1 fraksi senyawa.

\section{Hasil Kromatografi Lapis Tipis Hasil Fraksinasi}

Tabel 6. Hasil Pengamatan KLT Fraksi Kromatografi Vakum Cair

\begin{tabular}{|c|c|c|}
\hline Pengamatan & Fraksi & Rf \\
\hline $\begin{array}{l}\text { Pengamatan } \\
\text { pada UV }\end{array}$ & $\begin{array}{l}\text { 1. Fraksi etil asetat: } \\
\text { methanol }(7: 3) \mathrm{v} / \mathrm{v}\end{array}$ & \\
\hline \multirow[t]{9}{*}{$254 \mathrm{~nm}$} & - Spot 1 & 0,65 \\
\hline & $\begin{array}{l}\text { 2. Fraksi etil asetat: } \\
\text { methanol }(5: 5) \mathrm{v} / \mathrm{v}\end{array}$ & \\
\hline & - Spot 2 & 0,65 \\
\hline & $\begin{array}{l}\text { 3. Fraksi etil asetat: } \\
\text { methanol }(3: 7) \mathrm{v} / \mathrm{v}\end{array}$ & \\
\hline & $-\operatorname{spot} 3 A$ & 0,625 \\
\hline & - Spot 3B & 0,6625 \\
\hline & - Spot 3C & 0,70 \\
\hline & 4. Standar kinin & \\
\hline & - Spot 4 & 0,65 \\
\hline $\begin{array}{l}\text { Pengamatan } \\
\text { pada UV }\end{array}$ & $\begin{array}{l}\text { 1. Fraksi etil asetat: } \\
\text { methanol }(7: 3) \mathrm{v} / \mathrm{v}\end{array}$ & \\
\hline \multirow[t]{19}{*}{$366 \mathrm{~nm}$} & - Spot $1 A$ & 0,28 \\
\hline & - Spot 1B & 0,63 \\
\hline & - Spot $1 C$ & 0,81 \\
\hline & $\begin{array}{l}\text { 2. Fraksi etil asetat: } \\
\text { methanol }(5: 5) \mathrm{v} / \mathrm{v}\end{array}$ & \\
\hline & - Spot $2 A$ & 0,30 \\
\hline & - Spot 2B & 0,63 \\
\hline & $\begin{array}{l}\text { 3. Fraksi etil asetat: } \\
\text { methanol }(3: 7) \mathrm{v} / \mathrm{v}\end{array}$ & \\
\hline & - Spot 3A & 0,175 \\
\hline & - Spot 3B & 0,237 \\
\hline & - Spot 3C & 0,375 \\
\hline & - Spot 3D & 0,537 \\
\hline & - Spot 3E & 0,625 \\
\hline & - Spot 3F & 0,662 \\
\hline & - Spot 3G & 0,70 \\
\hline & - Spot 3H & 0,78 \\
\hline & 4. Standar Kinin & \\
\hline & - Spot 4A & 0,65 \\
\hline & - Spot 4B & 0,43 \\
\hline & - Spot 4C & 0,63 \\
\hline
\end{tabular}


Hasil Kromatografi Lapis Tipis Preparatif

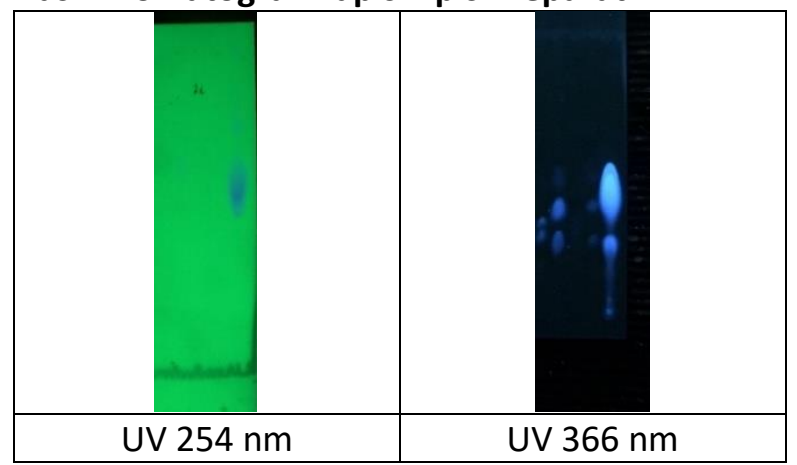

Gambar 2. Hasil subfrkasi KLT Preparatif di bawah sinar UV $254 \mathrm{~nm}$ dan $366 \mathrm{~nm}$ sesudah disemprot $\mathrm{H}_{2} \mathrm{SO}_{4} 10 \%$

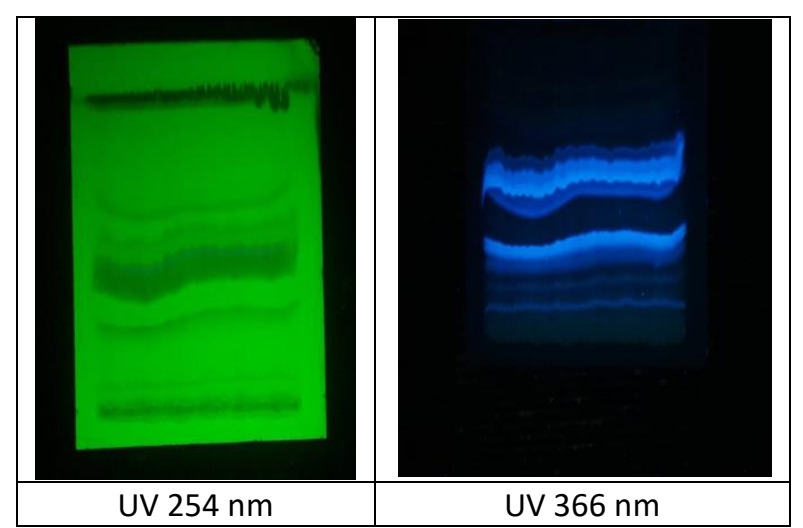

Gambar 3. Hasil subfrkasi KLT Preparatif di bawah sinar UV $254 \mathrm{~nm}$ dan $366 \mathrm{~nm}$ sebelum disemprot $\mathrm{H}_{2} \mathrm{SO}_{4} 10 \%$

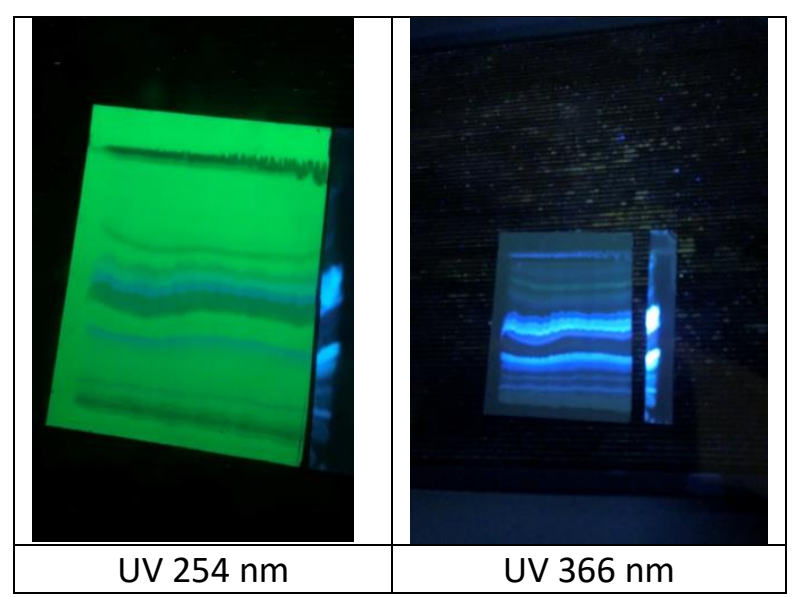

Gambar 4. Hasil subfrkasi KLT Preparatif di bawah sinar UV $254 \mathrm{~nm}$ dan $366 \mathrm{~nm}$ sesudah disemprot $\mathrm{H}_{2} \mathrm{SO}_{4} 10 \%$.

Keterangan:

Fase diam: KLT Al Silika Gel GF254

Fase gerak: $\mathrm{CHCl} 3: \mathrm{MeOH}(9: 1 \mathrm{v} / \mathrm{v})$

Penelitian KLT Preparatif dilakukan selama 2 minggu, pada minggu pertama diamati di bawah sinar UV $254 \mathrm{~nm}$ sebelum disemprot $\mathrm{H}_{2} \mathrm{SO}_{4} \quad 10 \%$ didapatkan hasil Rf 1 sebesar 0,1125, Rf 2 sebesar 0,3125, Rf 3 sebesar 0,425, Rf 4 sebesar 0,4875, Rf 5 sebesar 0,55, Rf 6 sebesar 0,625. Hasil di bawah sinar
UV $366 \mathrm{~nm}$ sebelum disemprot $\mathrm{H}_{2} \mathrm{SO}_{4} 10 \%$ adalah $\mathrm{Rf}$ 1 sebesar 0,05, Rf 2 sebesar 0,125, Rf 3 sebesar 0,2, Rf 4 sebesar 0,2625, Rf 5 sebesar 0,4375, Rf 6 sebesar 0,4875, Rf 7 sebesar 0,5625, Rf 8 sebesar 0,6625, Rf 9 sebesar 0,75, Rf 10 sebesar 0,7875, Rf 11 sebesar 0,9, Rf 12 sebesar 0,975. Hasil di bawah sinar UV 254 $\mathrm{nm}$ setelah disemprot $\mathrm{H}_{2} \mathrm{SO}_{4} 10 \%$ adalah $\mathrm{Rf} 4$ sebesar 0,2625 , Rf 7 sebesar 0,5625. Hasil di bawah sinar UV $366 \mathrm{~nm}$ setelah disemprot $\mathrm{H}_{2} \mathrm{SO}_{4} 10 \%$ adalah $\mathrm{Rf} 4$ sebesar 0,2625, Rf 7 sebesar 0,5625. Analisis kualitatif dilakukan pada penelitian ini dengan membandingkan Rf dan warna fluoresensi yang diperoleh dengan $\mathrm{Rf}$ dan warna fluoresensi standar kinin. Penelitian yang dilakukan pada minggu pertama berdasarkan hasil UV $366 \mathrm{~nm}$ setelah disemprot $\mathrm{H}_{2} \mathrm{SO}_{4} 10 \%$ terjadi pendaran biru intensif pada pita 4 dengan $\operatorname{Rf}$ 0,2625 dan 7 dengan $\operatorname{Rf}$ 0,5625 yang menandakan positif mengandung alkaloid kinin.

Minggu kedua dilakukan penelitian dengan prosedur kerja yang sama seperti minggu pertama dan didapatkan hasil jika diamati di bawah sinar UV $254 \mathrm{~nm}$ sebelum disemprot $\mathrm{H}_{2} \mathrm{SO}_{4} 10 \%$ adalah $\mathrm{Rf} 1$ sebesar 0,5, Rf 2 sebesar 0,237, Rf 3 sebesar 0,41, Rf 4 sebesar 0,625, Rf 5 sebesar 0,91. Hasil di bawah sinar UV $366 \mathrm{~nm}$ sebelum disemprot $\mathrm{H}_{2} \mathrm{SO}_{4} 10 \%$ adalah $\mathrm{Rf} 1$ sebesar 0,075 dengan warna fluoresensi hijau, Rf 2 sebesar 0,2125 dengan warna fluoresensi biru redup, Rf 3 sebesar 0,4375 dengan warna fluoresensi biru intensif, Rf 4 sebesar 0,95 dengan warna fluoresensi biru intensif, Rf 5 sebesar 0,3 dengan warna fluoresensi biru redup. Hal ini menandakan pada sinar UV $366 \mathrm{~nm}$ sebelum disemprot $\mathrm{H}_{2} \mathrm{SO}_{4} 10 \%$ terjadi pendaran biru intensif pada pita 4 dan 5 yang menandakan positif mengandung alkaloid kinin. Hasil pengamatan di bawah sinar UV 254 nm spot tidak berpendar. Hasil pengamatan di bawah sinar UV $366 \mathrm{~nm}$ setelah disemprot $\mathrm{H}_{2} \mathrm{SO}_{4} \quad 10 \%$ adalah $\mathrm{Rf} 3$ sebesar 0,25 dengan warna fluoresensi biru intensif dan $\mathrm{Rf} 4$ sebesar 0,4125 dengan warna fluoresensi biru intensif. Hal ini menandakan pada sinar UV 366 nm sebelum disemprot $\mathrm{H}_{2} \mathrm{SO}_{4} 10 \%$ terjadi pendaran biru intensif pada pita 3 dan 4 yang menandakan positif mengandung alkaloid kinin. Pita yang positif mengandung kinin kemudian dikerok dan 
dilanjutkan dengan proses ekstraksi menggunakan metanol $1 \mathrm{~mL}$ selama 1 hari. Kemudian disaring fraksi tersebut menggunakan pipet tetes yang didalamnya telah dimasukkan kapas. Fraksi ditampung dalam botol vial lalu diuapkan dan siap untuk diidentifikasi selanjutnya.

\section{Hasil KLT hasil Subfraksinasi}

Tabel 7. Plat KLT yang Diamati di bawah Sinar UV $254 \mathrm{~nm}$

\begin{tabular}{ccccc}
\hline Penotolan & $\begin{array}{c}\text { Jumlah } \\
\text { Spot }\end{array}$ & $\begin{array}{c}\text { Jarak } \\
\text { spot } \\
(\mathbf{x ~ c m})\end{array}$ & $\begin{array}{c}\text { Jarak } \\
\text { elusi } \\
(\mathbf{x ~ c m})\end{array}$ & $\begin{array}{c}\text { Rf } \& \\
\text { Hrf }\end{array}$ \\
\hline $\begin{array}{c}\text { Subfraksi } \\
\text { KLT-P IA }\end{array}$ & - & - & 8 & - \\
$\begin{array}{c}\text { Subfraksi } \\
\text { KLT-P IB }\end{array}$ & - & - & 8 & - \\
$\begin{array}{c}\text { Subfraksi } \\
\text { KLT-P IIA }\end{array}$ & - & - & 8 & - \\
$\begin{array}{c}\text { Subfraksi } \\
\text { KLT-P IIB }\end{array}$ & - & - & 8 & - \\
Standar & 1 & 3,8 & 8 & $\begin{array}{c}0,475 \\
\text { Kinin }\end{array}$ \\
\hline
\end{tabular}

Tabel 8. Plat KLT yang Diamati di bawah Sinar UV $366 \mathrm{~nm}$

\begin{tabular}{|c|c|c|c|c|}
\hline Penotolan & $\begin{array}{l}\text { Jumlah } \\
\text { Spot }\end{array}$ & $\begin{array}{c}\text { Jarak } \\
\text { spot } \\
(x \mathrm{~cm})\end{array}$ & $\begin{array}{l}\text { Jarak } \\
\text { elusi } \\
(x \mathrm{~cm})\end{array}$ & Rf \& Hrf \\
\hline \multirow{4}{*}{$\begin{array}{l}\text { Subfraksi } \\
\text { KLT-P IA }\end{array}$} & 1 & 2,2 & 8 & $0,27 \&$ \\
\hline & & & & 27 \\
\hline & 2 & 2,8 & 8 & $0,35 \&$ \\
\hline & & & & 35 \\
\hline \multirow{4}{*}{$\begin{array}{l}\text { Subfraksi } \\
\text { KLT-P IB }\end{array}$} & 1 & 2 & 8 & $0,25 \&$ \\
\hline & & & & 25 \\
\hline & 2 & 3,5 & 8 & $0,43 \&$ \\
\hline & & & & 43 \\
\hline Subfraksi & - & - & - & - \\
\hline \multicolumn{5}{|l|}{ KLT-P \|A } \\
\hline \multirow{4}{*}{$\begin{array}{l}\text { Subfraksi } \\
\text { KLT-P IIB }\end{array}$} & 1 & 2 & 8 & $0,25 \&$ \\
\hline & & & & 25 \\
\hline & 2 & 3,5 & 8 & $0,43 \&$ \\
\hline & & & & 43 \\
\hline \multirow{4}{*}{$\begin{array}{l}\text { Standar } \\
\text { Kinin }\end{array}$} & 1 & 2 & 8 & $0,25 \&$ \\
\hline & & & & 25 \\
\hline & 2 & 3,5 & 8 & $0,43 \&$ \\
\hline & & & & 43 \\
\hline
\end{tabular}

Plat KLT selanjutnya dianalisis pada sinar UV254 dan 366 nm yang pada sinar UV 254 terjadi pemadaman bercak karena yang berfluoresensi pada sinar UV 254 adalah plat KLT karena pada plat tersebut mengandung bahan yang dapat berfluoresensi. Pada UV 366nm sebelum penyemprotan, terlihat 4 spot yang terbentuk yang menandakan adanya kinin, yaitu subfraksi KLT-P IA dengan nilai Rf 0,27 dan 0,35, subfraksi KLT-P IB dengan nilai $\operatorname{Rf} 0,25$ dan 0,43, subfraksi KLT-P IIB dengan nili $\operatorname{Rf} 0,25$ dan 0,43, serta standar kinin dengan nilai $\mathrm{Rf} 0,25$ an 0,43 bercak yang dihasilkan menunjukkan warna biru. Hal tersebut terjadi karena senyawa kinin mampu berfluoresensi memberikan warna biru pada UV366 (Moffat et al., 2005).

Tabel 9. Plat KLT yang Diamati Di bawah Sinar UV 366 $\mathrm{nm}$ setelah disemprot dengan pereaksi $\mathrm{H}_{2} \mathrm{SO}_{4} 10 \%$

\begin{tabular}{|c|c|c|c|c|}
\hline Penotolan & $\begin{array}{c}\text { Jumlah } \\
\text { Spot }\end{array}$ & $\begin{array}{c}\text { Jarak } \\
\text { spot } \\
(x \mathrm{~cm})\end{array}$ & $\begin{array}{c}\text { Jarak } \\
\text { elusi } \\
(x \mathrm{~cm})\end{array}$ & $\begin{array}{c}\text { Rf \& } \\
\text { Hrf }\end{array}$ \\
\hline \multirow{6}{*}{$\begin{array}{l}\text { Subfraksi } \\
\text { KLT-P IA }\end{array}$} & 1 & 0,9 & 8 & 0,1125 \\
\hline & & & & $\& 11,25$ \\
\hline & 2 & 1,7 & 8 & 0,2125 \\
\hline & & & & $\& 21,25$ \\
\hline & 3 & 2,3 & 8 & 0,2875 \\
\hline & & & & $\& 28,75$ \\
\hline \multirow{6}{*}{$\begin{array}{l}\text { Subfraksi } \\
\text { KLT-P IB }\end{array}$} & 1 & 1 & 8 & 0,125 \& \\
\hline & & & & 12,5 \\
\hline & 2 & 1,8 & 8 & $0,225 \&$ \\
\hline & & & & 22,5 \\
\hline & 3 & 3,5 & 8 & 0,475 \& \\
\hline & & & & 47,5 \\
\hline \multirow{6}{*}{$\begin{array}{l}\text { Subfraksi } \\
\text { KLT-P IIA } \\
\text { Subfraksi } \\
\text { KLT-P IIB }\end{array}$} & 1 & 2,3 & 8 & 0,2875 \\
\hline & & & & $\& 27,5$ \\
\hline & 1 & 1,7 & 8 & 0,2125 \\
\hline & & & & $\& 21,25$ \\
\hline & 2 & 3,5 & 8 & 0,4345 \\
\hline & & & & $\& 43,45$ \\
\hline \multirow{4}{*}{$\begin{array}{c}\text { Standar } \\
\text { Kinin }\end{array}$} & 1 & 1,8 & 8 & $0,225 \&$ \\
\hline & & & & 22,5 \\
\hline & 2 & 3,4 & 8 & 0,425 \& \\
\hline & & & & 42,5 \\
\hline
\end{tabular}

Kinin mampu berfluoresensi karena memiliki struktur yang kaku dan kromofornya yang diperpanjang (Gandjar dan Rohman, 2012). Sistem rangkap terkonjugasi memiliki struktur yang planar dan kaku sehingga akan mampu menyerap secara kuat di daerah 200-800 $\mathrm{nm}$ pada radiasi elektromagnetik (Gandjar dan Rohman, 2007). Identifikasi bercak yang dihasilkan dilanjutkan dengan menggunakan pereaksi semprot $\mathrm{H}_{2} \mathrm{SO}_{4} 10 \%$. Pengamatan bercak pada sinar UV254 nm setelah disemprot dengan $\mathrm{H}_{2} \mathrm{SO}_{4} 10 \%$ menunjukkan bahwa bercak yang dihasilkan lebih banyak dari sebelum disemprotkan dengan $\mathrm{H}_{2} \mathrm{SO}_{4} 10 \%$. Hal tersebut dapat terjadi karena $\mathrm{H}_{2} \mathrm{SO}_{4} \quad 10 \%$ dapat meningkatkan intensitas fluoresensi senyawa kinin, sehingga bercak akan tampak lebih banyak setelah direaksikan 
dengan $\mathrm{H}_{2} \mathrm{SO}_{4} 10 \%$. Setelah penyemprotan pada UV $366 \mathrm{~nm}$, bercak yang terbentuk 5 spot yaitu subfraksi KLT-P IA dengan nilai Rf 0,1125:0,2125:0,2875, subfraksi KLT-P IB dengan nilai Rf 0,125; 0225 ; 0,475, subfraksi KLT-P IIA dengan nili Rf 0,2875, subfraksi KLT-P IIB dengan nilai Rf 0,2125:0,4345 serta standar kinin dengan nilai Rf 0,225 adn 0,425. Interpretasi data yaitu pengamatan UV $245 \mathrm{~nm}$ sebelum disemprot spot yang sama yaitu standar kinin. Pengamatan di bawah sinar UV 366 sebelum disemprot didapatkan subfraksi KLT-P IB dengan Rf 0,25 dan KLT-P II B dengan Rf 0,43 yang paling sama dengan standar kinin yang mana $\mathrm{Rf}$ standar kinin yaitu 0,25 dan 0,43 dan berfluoresensi biru intensif sehingga fraksi yang digunakan selanjutnya yaitu fraksi KLT-P IB dan KLT-P IIB. Pengamatan pada sinar UV $366 \mathrm{~m}$, setelah disemprot memiliki Rf dan spot yang sama dimana subfraksi KLT-P I B dengan Rf 0,125; 0,225 dan 0,475 dan subfraksi KLT-P IIB dengan $\mathrm{Rf} 0,2125$ dan 0,4375 didapatkan fraksi yang sama dengan standar kinin dimana rf nya adalah 0,225 dan 0,425 sehingga fraksi yang digunakan selanjutnya yaitu subfkasi KLT-P I B dan KLT-P II B.

\section{Hasil Identifikasi dengan Metode KLT-Densitometri}

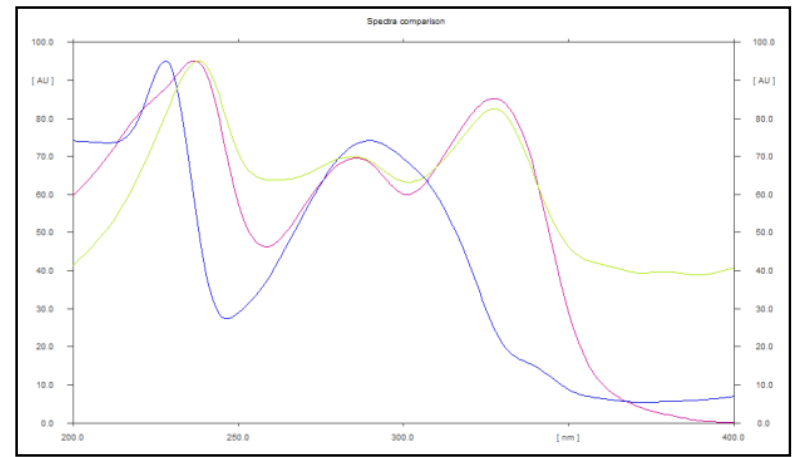

Gambar 5. Sprektrum Standar Kinin (merah muda), Ekstrak Metanol (biru), dan Hasil Subfraksinasi KLT$P$ (kuning muda)

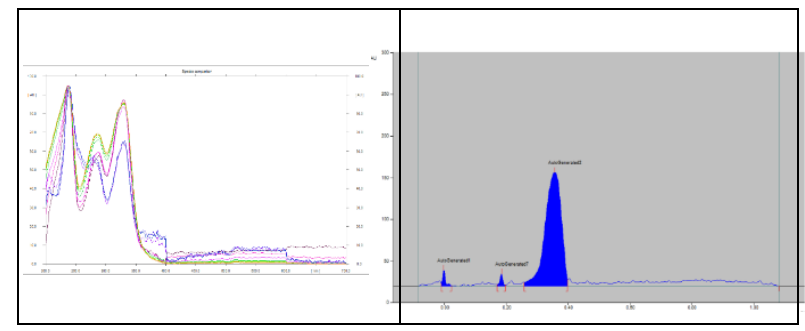

Gambar 6. Spektrum dan Kromatogram Standar Kinin

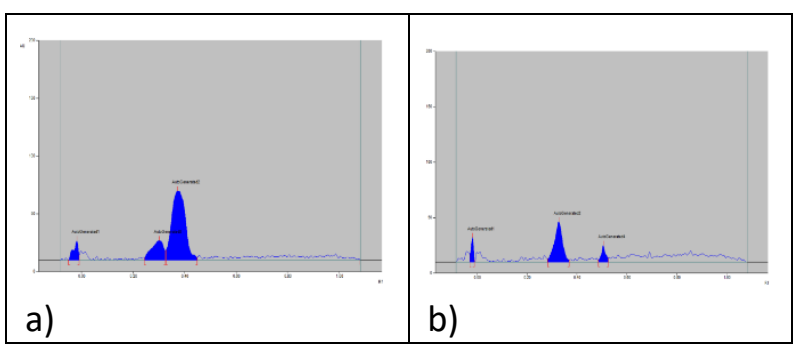

Gambar 7. a) Spektrum Subfraksi l; b) Spektrum Subfraksi II

\section{Kurva Kalibrasi Larutan Seri}

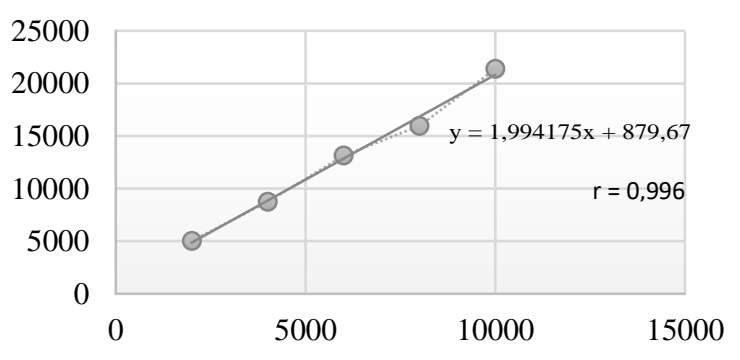

Gambar 8. Kurva Kalibrasi (Hubungan AUC dengan Konsentrasi Larutan Seri)

Pengukuran kadar suatu senyawa dengan sistem Densitometri mode absorpsi dilakukan dengan mengukur serapan dari analit yang menyerap sinar UV sebab senyawa yang ditentukan kadarnya tidak berfluoresensi. Adanya gugus kromofor dari analit akan berinteraksi dengan radiasi elektromagnetik dari sumber lampu UV, mengakibatkan eksitasi elektron ke tingkat energi yang lebih tinggi. Pada proses eksitasi ini, akan diserap energi yang terukur sebagai absorbansi. Absorbansi ini akan dideteksi oleh detektor dari spektrofotodensitometer. Dimana metode ini merupakan suatu metode yang dapat digunakan untuk melakukan suatu analisis baik analisis kualitatif dan kuantitatif. Dimana analisis kualitatif merupakan suatu metode yang dapat digunakan untuk mengetahui ada atau tidaknya suatu senyawa yang ingin dicari dalam suatu komponen atau tumbuhan sedangkan analisis kuantitatif merupakan suatu metode yang digunakan untuk mengetahui kadar dari analit yang sedang dianalisis (Gandjar dan Rohman, 2007).

Hasil dari proses pengukuran menggunakan densitometer tersebut ditemukan peak baik itu larutan uji standar kinin, dan larutan subfraksinasi hasil KLT-P I dan II. Hasil yang diaperoleh dari dengan menggunakan metode KLT-densitometri nilai rf, 
spektrum dan AUC. Rf dan spekrum digunakan untuk analisis kualitatif sedangkan AUC dipergunakan untuk analisis kuantitatif. Berdasarkan data AUC dari standar maka diperoleh kurva kalibrasi dengan persamaan $y=1,994175 x+879,67$ dengan nilai $r=$ 0,996 . Dilihat dari nilai $r$ mendekati 1 , maka persamaan regresi tersebut memenuhi persyaratan linieritas. Kemudian dilakukan penetapan kadar seri dengan 5 konsentrasi berbeda diperoleh hasil kadar berturut-turut yaitu 1039,384 $\mu \mathrm{g} / \mathrm{mL}$; 987,492 $\mu \mathrm{g} / \mathrm{mL}, 1022,714 \mu \mathrm{g} / \mathrm{mL}, 945,305 \mu \mathrm{g} / \mathrm{mL}$ dan $1027,253 \mu \mathrm{g} / \mathrm{mL}$. Diperoleh \% recovery dari masingmasing seri $1,2,3,4$, dan 5 berturut-turut yaitu $103,938 \% ; 98,749 \% ; 102,271 \% ; 94,531 \%$ dan $102,725 \%$. sehingga diperoleh rata-rata \% recovery sebesar $100,442 \%$.

Kandungan minimal alkaloid dalam tanaman kina adalah 6,5\%, dimana 30-60\% merupakan alkaloid kinin dan kandungan kinin dalam kulit batang kina liar adalah 7\% sedangkan untuk tanaman kina yang dibudidayakan dapat mengandung alkaloid kinin sampai 15\% (Misra et al., 2008). Jadi, dalam 25 mg serbuk kina yang diekstraksi menggunakan metode Soxhlet diperoleh kadar kinin dengan jumlah yang sangat sedikit hal ini disebabkan oleh metode preparasi sampel yang dilakukan, karena pemisahan yang tidak baik menyebabkan kadar kinin yang terdeteksi menjadi sangat kecil.

\section{SIMPULAN}

Berdasarkan hasil identifikasi dan penetapan kadar dengan metode KLT-Densitometri bahwa sampel positif mengandung kinin dan diperoleh perhitungan kadar kinin. Penetapan kadar total kinin dalam standar kinin menghasilan nilai rata-rata \% recovery yaitu 100,442 \% dan kadar total kinin dalam subfraksi KLT-P I dan II secara berturut-turut menghasilkan kadar sebesar 0,402612 mg/mL dan $0,155830 \mathrm{mg} / \mathrm{mL}$ dengan nilai kadar rata-rata yaitu $0,279221 \mathrm{mg} / \mathrm{mL}$.

\section{DAFTAR PUSTAKA}

Amalia, E., Parwati, T., dan Simanjuntak, P. (2004). Produksi Asam Lemak Oleat oleh Mikroba Endofit Sporodiobolus salmonicolor dan Tumbuhan Kina (Cinchona pubescens Vahl.). Pusat Penelitian Bioteknologi LIPI.

Depkes RI., (2014). Farmakope Indonesia. Edisi Kelima. Departemen Kesehatan Republik Indonesia.

Depkes RI., 1995. Farmakope Indonesia. Edisi Keempat. Departemen Kesehatan Republik Indonesia

Eagleson, M. (1993). Concise Encyclopedia Chemistry. Walter de Gruyter.

Gandjar, I. G., \& Rohman, A. (2007). Kimia Farmasi Analisis. Pustaka Pelajar.

Gandjar, I. G., \& Rohman, A. (2012). Analisis Obat secara Spektroskopi dan Kromatografi. Pustaka Pelajar.

Harborne, J.B., (1987). Metode Kimia Penuntun Cara Modern Menganalisis Tumbuhan. Penerbit ITB.

Harijanto., \& Paul, N. (2006). Buku Ajar Ilmu Penyakit Dalam. Jilid III edisi V. Pusat Penerbitan Departemen Ilmu Penyakit Dalam.

Kristanti, A. N., Aminah, N. S., Tanjung, M., Kurniadi, B. (2008). Buku Ajar Fitokimia. Jurusan Kimia Laboratorium Kimia Organik FMIPA Universitas Airlangga.

Leliqia, N.P.E., Ariantari, N.P., Warditiani, N.K., Paramita, N.L.P.V., Samirana, P.O., Putra., A.A.R.Y. (2019). Petunjuk Praktikum Fitokimia. Jurusan Farmasi FMIPA Universitas Udayana.

Merck, I. (2001). An Encyclopedia of Chemicals, Drugs, and Biologicals. 13th Edition. Merck \& Co Inc. 
Misra, H., Metha, B. K., \& Jain, D. C. (2008). Optimization of Extraction Conditions and HPTLC -UV Methodfor Determination of Quinine in Different Extracts of Cinchona species Bark. Rec. Nat. Prod. 2(4), 107-115.

Moffat, C. A., Osselton, M. D., Widdop, B. (2005). Clarke's Analysis of Drugs and Poisons, In Pharmaceuticals, Body Fluids, and Postmortem Material. 3 rd Edition. Pharmaceutical Press.
Stahl, E. (1985). Analisis Obat Secara Kromatografi dan Mikroskopi. Penerbit ITB.

Wink, M. (2008). Ecological Roles of Alkaloid. VCH Verlag Gmbh \& Co. KgaA. 